\title{
Physical and Chemical Fruit Quality Attributes of Two Pomegranate Cultivars Grown at Varying Altitudes of Al-Hajar Mountains in Oman
}

Basim S. AL-Kalbani ${ }^{12^{*}}$, Rashid A. Al-Yahyai ${ }^{1}$, Abdullah M. Al-Sadi ${ }^{1}$, Al-Ghaliya H. Al-Mamari ${ }^{2}$

$$
\begin{aligned}
& \text { الحُصائص الفيزيائية والكيميائية لجودة صنفين من فاكهة الرمان يزرعان على فيلى }
\end{aligned}
$$

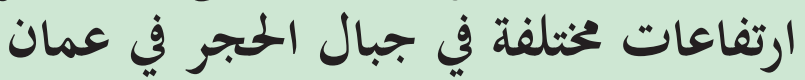

$$
\begin{aligned}
& \text { باسم الكلباني , راشد اليحيائي , عبدالله السعدي , الغالية المعمري }
\end{aligned}
$$

AbSTRACT. The present study investigated the differences in fruit physical and chemical quality characteristics of two popular local pomegranate cultivars, namely Helow and Malasi, as influenced by the altitudinal microclimates. Three sites of varying altitudes were selected for this study at Al-Hajar Mountains in northern Oman that included, high (2019 $\mathrm{m}$, Saiq), mid (1876 m, Sograh) and low altitudes (1540 m, Wakan). The results showed that at lower altitudes of Wakan, the Malasi cultivar had better color attributes than Helow cultivar. Malasi also had more lightness (L), yellowness (b) and color intensity (chroma) but less greenness (a), while in mid-altitude, Helow had better color compared with Malasi cultivar. Furthermore, Helow colors was developed as evidenced in terms of brightness, skin and arils redness at higher altitude compared to the two lower altitude sites. Physical fruit qualities were also investigated and the results indicated that in most measured parameters, the Malasi fruit quality was better in both locations (Sograh and Wakan) than Helow cultivar, while Helow cultivar had superior fruit quality at higher elevation in Saiq. Additionally, Malasi had higher juice volume (JV), total soluble solid (TSS) and titratable acidity (TA) than Helow in Wakan. Helow fruits in Saiq showed better performance and higher results for juice volume (JV), total soluble solid (TSS) and maturity index (MI) as followed by those in Sograh and Wakan. Our study showed that the fruit physical and chemical quality attributes of local pomegranate cultivars are strongly influenced by growing location and altitude.

KEYWORDS: pomegranate, physical and chemical quality, altitudes, microclimates

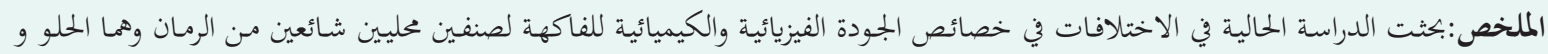

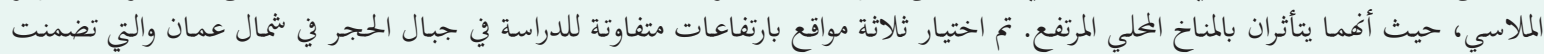

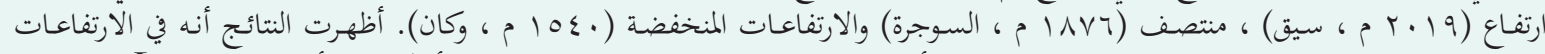

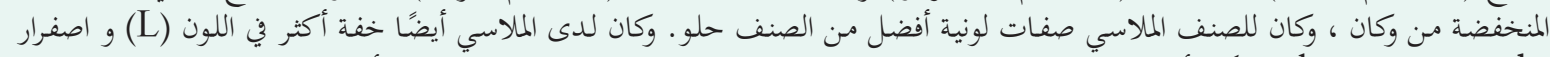

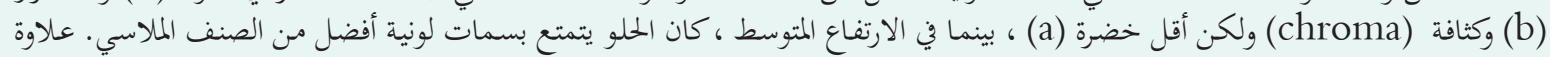

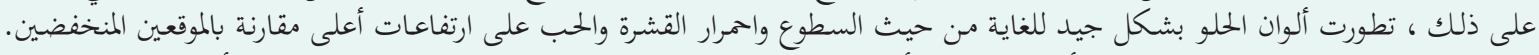

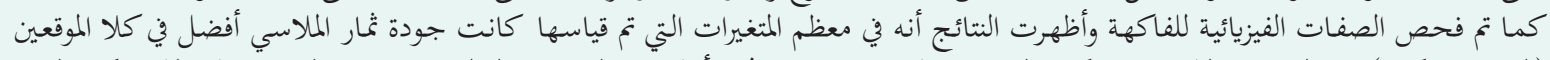

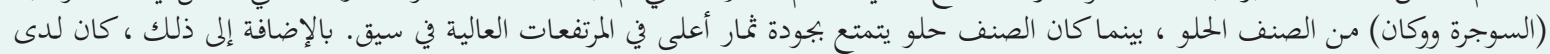

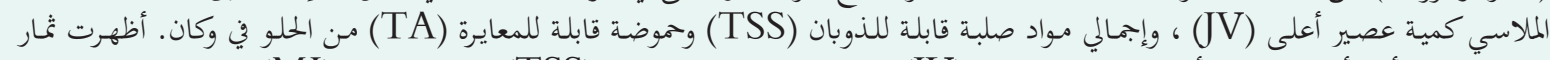

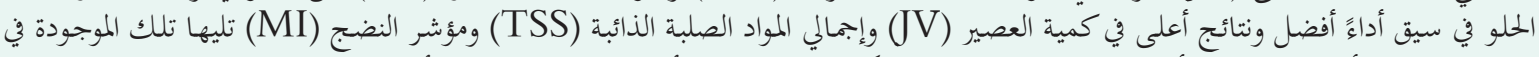

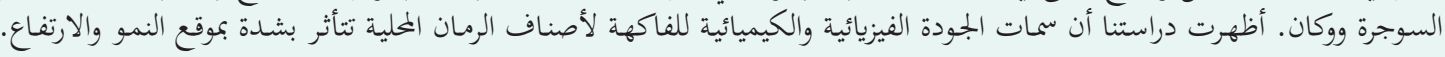

$$
\begin{aligned}
& \text { الكلمات المفتاحية: الرمان ، الجودة الفيزيائية والكيميائية ، الارتفاعات ، المناخ. }
\end{aligned}
$$

\section{Introduction}

$\mathrm{F}$ ruit quality of pomegranate is affected by climatic and cultural variables, especially for cultivars that are grown in marginal lands, such as those cultivated in Al-Hajar Mountains of Oman (Al-Said et al., 2009). Pomegranate is one of the main fruit crops grown in the northern Oman in Al-Hajar Mountain at an altitude of 2000-3000 m above sea level (Al-Said et al., 2009; Al-Yahyai et al., 2009). Omani pomegranates

Basim S. Al-Kalbani 1,2; (- basem87alkalbani@gmail.com, ${ }^{1}$ Department of Plant Sciences, College of Agricultural and Marine Sciences, Sultan Qaboos University, Al-Khod, Sultanate of Oman, ${ }^{2}$ Directorate General of Agriculture and Livestock Research, Ministry of Agriculture, Muscat, Sultanate of Oman have a special economic significance in the growing regions of Oman and have attracted customers worldwide, primarily tourists and residents from neighboring Gulf Cooperation Council (GCC) countries leading to a great demand of fruits during harvesting time in September every year and huge potential for expansion of cultivated area (Al-Said et al., 2013). Pomegranate is one of the most important fruit crops that gained interest in recent years and currently produced widely around the world. India, Iran, Turkey, China and USA are the leading pomegranate producers and more than $76 \%$ of the pomegranate fruits world export is from these countries (Martínez-Nicolás et al., 2019). Pomegranate fruit quality is important to increase the profits of producers. 
Fruit physico-chemical qualities plays an important role in defining price structure of pomegranate fruits (AlSaid et al., 2009). High demand of pomegranate fruits in the world is because of its health benefits from the juice, arils, dehydrated seeds, rind and other parts of the fruit (Melgarejo et al., 2013).

The local cultivars grown in Oman, are Helow, Qusum, Malasi and Hamedh. The Helow cultivar is the most popular with the sweetest taste which occupies the largest cultivated area (Al-Yahyai et al., 2009). Undesirable characteristics of the other cultivated cultivars like Qusum having hard seeds Malasi smaller in size smoother skin being more susceptible to bruising. Similarly, Hamedh is a wild cultivar that usually grows on the edges of farms, has highly acidic taste and small fruit size with undesirable eating quality (Al-Said et al., 2009).

Pomegranate quality depends on the factors, such as climate, cultivar, growing conditions, maturity and cultural practices. It is important to select suitable climatic conditions to cultivate the best cultivar of pomegranate with desirable quality fruit (El-Salhy et al, 2019). There is variability in performance of these cultivars in different agro-climatic conditions (El-Salhy et al., 2019). Despite its great international success, 'Wonderful' is one of commercial pomegranate cultivar which has not done well in pomegranate growing regions of Oman. Mphahlele et al. (2016) conducted a study which showed that 'Wonderful' pomegranate quality and the maturity stage affected its biochemical and aroma volatile attributes under different agro-climatic locations (altitudes). Like pomegranates, Naryal et al. (2019) showed that the fruit sugar contents and sugar profiles of dried apricot (Prunus armeniaca L.) affected when cultivated at different altitudes. Further, Boussaa et al. (2020) found that physical properties of pomegranate, such as bioactive compounds, and antioxidant activity also changed with altitude. Peng et al. (2020) grouped 37 varieties of pomegranate in China into three categories based on cluster analysis after analysis of fruit physico-chemical quality parameters. In Al-Hajar mountain, fruits cultivars differ with different elevations. In Saiq (altitude, 2019 m above sea level), Helow cultivar is the dominant among cultivars as compared to Malasi which is dominant in Wakan at (altitude, $1540 \mathrm{~m}$ ) and Sograh (altitude, $1876 \mathrm{~m}$ ). This present study investigated the effects of growing at different altitudes on pomegranate fruit and aril physical and chemical quality characteristics of two major cultivars (i.e. Helow and Malasi).

\section{Materials and Methods}

\section{Sample Collection}

Three locations in Al-Hajar Mountain were selected from Al-Jabal Al-Akhdar and Wadi Mastel where pomegranate is commonly cultivated as the primary fruit crop. Two locations in Al-Jabal Al-Akhdar namely; Saiq
(23.0872618 latitude, 57.6938060 longitude and 2019 $\mathrm{m}$ altitude) and Sograh (23.144504 latitude, 57.672766 longitude and $1876 \mathrm{~m}$ altitude) were used. Other location from Wadi Mastel, Wakan, (23.1421282 latitude, 57.7340133 longitude and $1540 \mathrm{~m}$ altitude) was used. Fruits were harvested from farmers' field during two years 2018 and 2019. Fruits were hand-picked at skin color change (maturity index) commercial ripening time. Fruits were harvested during the month of September. In Wakan and Sograh, two pomegranate cultivars 'Helow' and 'Malasi' were selected for the study and one cultivar 'Helow' from the 3rd site, i.e. Saiq. Ten 'Malasi' and five 'Helow' trees were selected for fruit harvest, due to the limited number of representative trees. Five mature fruits per tree were collected for physical and chemical quality measurements.

\section{Analysis of Fruit Physio-chemical Characteristics}

Color: Color measurements were performed using a colorimeter (Model CR 200, Minolta, Milton Keynes, UK). Fruit color (FC) measurements were taken along the equatorial axis of three selected fruit. Three readings of each color index $\left(L^{*} a^{*} b\right)$ were taken per fruit, given a total measurement per fruit sample, where $L$ is difference in lightness/darkness value. Negative (L) values indicate darkness and higher positive (L) values indicate lightness. On the other hand, negative (a) values indicate green and higher positive (a) values indicate red color. Higher positive (b) values indicate a more yellow skin color and negative (b) indicate a blue color. These values were then used to calculate hue degree, where $0^{\circ}$ $=$ red-purple, $90^{\circ}=$ yellow, $180^{\circ}=$ bluish green, and $270^{\circ}$ = blue, and (Chroma), which indicates the intensity or color saturation (Selcuk and Erkan, 2015). Chroma and hue were calculated as follows:

$$
\text { Chroma }=\sqrt{ }\left(a^{* 2}+b^{* 2}\right)
$$

Hue $=\arctan \left(\mathrm{b}^{*} / \mathrm{a} *\right)$

Also arils color was measured with the same colorimeter from tow fruit sample per tree and three readings from each fruit.

Physical quality parameters of fruits and arils: The length and diameter of the fruit and arils were determined with a digital venire caliper while the weight was determined using a weighing balance. Three mature fruits from each tree were taken from Helow and Malasi cultivars. Fruit total length (FL2), fruit total length excluding the calyx (FL1), calyx diameter (FD2), fruit equatorial diameter (FD1), and fruit skin thickness (Ec). Arils maximum width $(\mathrm{Sw})$ and arils length $(\mathrm{SL})$ were measured. Three arils were used from each fruit sample. Also the seeds of the arils were used to determine width (w), length (L) and weight of woody portion (WPW). Fruits were weighed using a balance of exactitude of $0.001 \mathrm{~g}$. Fresh weights (FW) were taken for three fruits per tree. Rind weight plus weight of capillary membranes (PcMc), aril weight (AW) and weight of woody portion (WPW) inside the aril were measured. Number of carpels (Nc) 
in each fruit were also counted. The arils were removed from the fruit and arils fresh weight or arils yield (Rs) were determined (Rs=FW- PcMc).

Chemical quality parameters of fruits: The fruits were peeled and the skin covering the arils was removed. The juice was extracted from pomegranate arils using a juice extractor. The juice was used to determine juice volume (JV) and the chemical properties of each individual fruit and replicated according to the type of measurements. Total soluble solids (TSS) (Brix) were determined on three fruit samples per tree using a temperature compensating hand-held refractometer. Juice acidity was measured using three samples per fruit. Percentage of titratable acidity (TA), expressed as percent citric acid, was determined using a $10 \mathrm{ml}$ homogenized extracted juice sample. The juice sample was added to $10 \mathrm{ml}$ distilled water. Aliquot of $20 \mathrm{ml}$ were titrated with $0.1 \mathrm{M}$ $\mathrm{NaOH}$ until the color changed to pink as indicated by phenolphthalein indicator (AOAC, 2000). Three homogenized samples per cultivar were analyzed for TA.

\section{Statistical analysis}

The experimental design used was a Completely Randomized Design (CRD). Statistical analysis was done by SAS software using Duncan's Multiple Range Test (SAS Institute, Cary, N.C.). Treatment means were compared using Duncan's Multiple Range Test at $\mathrm{P} \leq 0.05$.

\section{Results}

\section{Effect of Locations and Cultivars on Color Parameters}

Effects of location on the color parameters of Helow and Malasi cultivars and difference among the cultivars (Helow or Malasi) in different locations are shown in Table 1. All cultivars showed significant differences between locations in fruit and arils color parameters except Malasi, which showed no significance different between different locations in arils color. In the lower altitude, Wakan, Malasi cultivar showed higher values in all fruit color parameters than Helow cultivar, where Malasi had more brightness (L), yellowness (b), intense (Chroma) and less greenness (a). Hue values from fruits in Wakan showed that both cultivars were from red to purple, as degree near to zero. In the middle altitude, Sograh, Helow cultivar had more brightness, greenness and yellowness while Malasi was more intensely red. Arils color in Wakan and Sograh showed that Helow cultivar had brighter color and yellower than Malasi, which had more intensely red color. Hue was same as in Wakan that both cultivars were from red to purple as degree near to zero. In the higher altitude, Saiq, Helow cultivar was dominantly cultivated. Helow cultivar in Saiq showed higher red (a), less yellowness (b) and less intense (Chroma) in fruit color than Sograh and Wakan. Aril color of Helow fruits was brighter, yellower and less intensely red at lower altitudes (Wakan and Sograh) than at highest altitude (Saiq). On the other hand, fruit color of Malasi cultivar was brighter, yellower and more intense at lower altitudes (Wakan). Malasi cultivar showed more red in color in Sograh than Wakan. Arils color of Malasi cultivar had same brightness, yellowness and intensely same in lower and middle altitudes. Fruit and aril differences among cultivars and locations in color are shown in Figure 1. Fruit and aril color development varies among growing altitudes and between cultivars. Color of Helow cultivar was more affected by location compared with Malasi. Helow cultivar in lower altitudes (Wakan) showed lower brightness (L), less red and intensely in color comparing to Helow and Malasi cultivars in same, middle (Sograh) and higher (Saiq) altitudes in fruits and arils color parameters. Malasi in Wakan was brighter and yellower in fruit color. Malasi arils In Wakan and Sograh higher red in color comparing to the cultivars in the other altitudes.

\section{Effect of Locations and Cultivars on Physical and Chemical Quality Parameters}

The effects of locations and cultivars on fruit quality properties were tested by comparing fruit weight (FW), total fruit length (FL), fruit length without calyx (FL1), calyx length (CL), fruit diameter (FD), calyx diameter (CD), number of carpels (Nc), rind weight plus weight of capillary membranes (PcMc), skin thickness (Ec) and arils yield (Rs) of Helow and Malasi cultivars in Saiq, Sograh and Wakan (Table 2). All physical and chemical quality parameters between locations were significantly different except for the number of carpels $(\mathrm{Nc})$, skin thickness (Ec) and arils yield (Rs). Also cultivars were significant different $(\mathrm{P}<0.05)$ in all parameters except number of carpels $(\mathrm{Nc})$.

Starting with Wakan, the results showed Malasi cultivar was significantly better than Helow in fruit weight (FW), total fruit length (FL), fruit length without calyx (FL1), fruit diameter (FD) and rind weight plus weight of capillary membranes (PcMc) (Table 2), while Helow cultivar had higher calyx diameter (CD). In Sograh, there was no significance different in fruit weight (FW) between Malasi and Helow cultivars but Malasi had more total fruit length (FL), fruit length without calyx (FL1), fruit diameter (FD), calyx diameter (CD) and rind weight plus weight of capillary membranes (PcMc). However, Sograh showed same results when comparing between Helow and Malasi cultivars as Wakan which was illustrated previously. Over all, Malasi cultivar performed better in Wakan and Sograh than Helow cultivar. Helow in Saiq was the best in all fruit physical quality parameters than the other locations. It was higher in fruit weight (FW), total fruit length (FL), fruit length without calyx (FL1), calyx length (CL), fruit diameter (FD), calyx diameter (CD) and rind weight plus weight of capillary membranes (PcMc). Helow cultivar in Wakan had calyx length (CL) and calyx diameter 


\begin{tabular}{|c|c|c|c|c|}
\hline (1) Saiq & \multicolumn{2}{|c|}{ (2) Sograh } & \multicolumn{2}{c|}{ (3) Wakan } \\
\hline Helow fruit and arils & Helow fruit and arils & Malasi fruit and arils & Helow fruit and arils & Malasi fruit and arils \\
\hline & & & & \\
& & & & \\
& & & & \\
\hline & & & & \\
\hline
\end{tabular}

Figure 1. Fruits and arils of Helow and Malasi cultivars in Saiq, Sograh and Wakan.

(CD) similar to Helow in Saiq. However, there was no significant difference between Saiq and Wakan in calyx length $(C L)$ and calyx diameter $(C D)$ but there was a significant difference from Helow in Sograh, which was lower. Also there was no significance different between Helow in Saiq and Sograh in fruit diameter (FD), total fruit length (FL), fruit length without calyx (FL1) but there was a significant difference from Helow in Wakan which was showed lower on previous parameters. Results clearly indicated that fruit weight (FW) and rind weight plus weight of capillary membranes (PcMc) were significantly higher $(\mathrm{P}<0.05)$ in Saiq than Sograh followed by Wakan. Over all Malasi cultivar quality performed better in Sograh and Wakan, while Helow cultivar was better in higher elevation in Saiq. There was no interaction between cultivars and locations in all fruit physical quality parameters as showed in Table 2 .

The effects of locations and cultivars on fruit quality properties (physical and chemical of fruit quality parameters) were tested by comparing arils width (SW), arils length (SL), Aril weight (AW), juice volume (JV), total soluble solid (TSS), titratable acidity (TA), maturity index (MI), seed width (W), seed length (L), woody portion weight (WPW) and woody portion index (WPI) of Helow and Malasi cultivars in Saiq, Sograh and Wakan (Table 3). Location effects were significantly different with respect to all arils and chemical parameters while cultivars were significantly different with all except arils length (SL), woody portion weight (WPW) and woody portion index (WPI). Firstly, comparing Malasi and Helow cultivars in Wakan, the results showed that Malasi had more aril weight (AW), juice volume (JV), total soluble solid (TSS), titratable acidity (TA) and seed width (W) while Helow had higher arils length (SL), maturity index (MI) and seed length (L). Malasi had better aril quality than Helow in Wakan. Secondly, Malasi showed higher chemical quality parameters [juice volume (JV), total soluble solid (TSS), titratable acidity (TA) then
Helow which showed higher physical quality parameters (arils length (SL), aril weight (AW), maturity index (MI), seed width (W) and seed length (L)]. Comparing Malasi cultivars between Wakan and Sograh, it was found that there was no significance different in juice volume (JV), total soluble solids (TSS) and seed length (L). Wakan had higher arils width (SW), aril weight (AW) and seed width (W) while in Sograh, Malasi cultivar showed higher arils length (SL), titratable acidity (TA), maturity index (MI), woody portion weight (WPW) and woody portion index (WPI).

On the contrary, comparing Helow cultivar in the three locations it was observed that higher arils width $(\mathrm{SW})$, arils length (SL), aril weight (AW), titratable acidity (TA) and seed width (W) were found in Sograh but there was no significance different between Sograh and Saiq in aril weight (AW) and Sograh and Wakan in titratable acidity (TA). There was no significant difference between the three locations in seed length (L). Saiq Showed higher results for Juice volume (JV), total soluble solids (TSS), maturity index (MI), woody portion weight (WPW) and woody portion index (WPI), followed by Sograh and after that Wakan. Overall, Helow cultivar performed better at higher altitude in Saiq, compared with Sograh and the least was for lowest altitude which was Wakan. As the elevation decreased the physical and chemical quality parameters of Helow cultivar decreased. In Malasi there was not much difference between Sograh and Wakan in physical and chemical quality parameters, which was not commonly grown in high elevation areas like Saiq as has been reported by farmers.

Interaction between locations and cultivars also was illustrated in Table 3. Arils physical quality properties showed no significant interaction except in arils weight which showed higher arils weight (AW) in Helow cultivar in Saiq while Helow in Wakan was the lowest. There was no significant difference between Helow in Saiq and Sograh and also between Malasi in Sograh 
and Wakan. In seed, physical quality properties there was no interaction except width of the seeds, which was higher in Malasi than Helow in Wakan. The difference in arils weight (AW) and seed width (W) was not high because it differs $(0.1 \mathrm{mg})$ in arils weight and $(1.0 \mathrm{~mm})$ in seed width. Arils chemical quality properties highly interact between locations and cultivars. Helow in Saiq had higher juice volume (JV) followed by Helow and Malasi of Sograh. Also there were no significant differences between Malasi in Sograh and Wakan and Helow of Wakan where it was the least. Malasi showed higher (TSS) and (TA) than Helow cultivars in all locations. Malasi in Sograh was the highest followed by Malasi of Wakan then Helow of Saiq followed by Helow of Sograh, where Helow of Wakan were the lowest. It was clearly seen that in Helow cultivar, TSS decreased as the elevation decreased. Titratable acidity (TA) also was higher in Malasi of Sograh than Wakan followed by Helow of Wakan. Helow of Wakan and Sograh showed no significant difference with Helow in Sograh and Saiq, which was the lowest. Maturity index (MI) decreased as elevation decreased in Helow cultivar, which was higher than Malasi cultivar. There was no significant difference between Malasi in Wakan and Sograh in (MI).

\section{Discussion}

\section{Experiment on Physical and Chemical Description of Pomegranate Fruits}

Effect of locations and cultivars on color parameters: Color parameters of Helow and Malasi cultivars of pomegranate fruits grown in Saiq, Sograh and Wakan were significantly different. Fruit brightness as determined by $\mathrm{L}$ value at CIELAB scale, showed that the lower altitude Wakan fruits were brighter in color than mid-elevation Sograh in Malasi cultivar, and lowest in Helow cultivar than Sograh followed by Saiq. Fruit brightness (L) indicated how light colors developed in the fruit at the time of harvest and can be attributed to many variables, including the development of other colors (such as tallow background, green, and red colors). In fruits, González et al. (2011) suggested that the change in L value may be attributed to genetic variability among genotypes, which is evident when comparing two cultivars grown in the same location. The increase of $\mathrm{L}$ values may be related also to degradation of chlorophyll as fruits turn red with a differential susceptibility to degradation of chlorophylls among genotype (Kumari et al., 2019). In terms of red color of fruits, $a^{*}$ value results showed as the elevation increase red color also increased while yellowness $b *$ increased inversely with elevation which was observed for both cultivars. Different trees gown at different elevations are exposed to different microclimatic conditions (such as temperature and relative humidity), which highly influence the coloration of the fruits. This was observed in the color de- velopment of deciduous fruits such as in the case of skin color of apple by increasing the carotenoids because of the temperature factor (González et al., 2011). In peach the high-altitude improved skin red blush intensity June Gold cultivar (Karagiannis et al., 2016). Environmental factors like day/night temperature, solar radiation wave lengths or a mixture of these factors can control fruit ripening and the variances between these environmental factors growing with altitude, and it determined the fruit quality at harvest (Kumari et al., 2019). Nour et al. (2015) found that the red color was the product of chlorophyll degradation and synthesis of lycopene and other carotenoids, as chloroplasts converted into chromoplasts (Bilalis et al., 2018). Hue value which was indicated in Table 1 showed that the fruits ranged from red to purple color as the degree ranged from (0 to 90). Also intensity of color (Chroma) was higher in Malasi then Helow and as elevation increased intensity decreased and that because of increased in temperature as elevation decreased as found in fruit color tomato by Nour et al. (2015). Higher mean air temperature in the fruiting stage during the second year of the study resulted in more reddish tomato fruits because color saturation increases during the ripening of tomato fruits (Bilalis et al., 2018). Also in arils, our finding showed that cultivars varied in size of fruits and fruit and aril color at maturity stage (Al-Said et al., 2009). So different elevations lead to different climate conditions (light intensity, temperature and relative humidity) which effect on the color parameters of fruits.

Effect of locations and cultivars on physical and chemical quality of pomegranates: The effects of locations and cultivars were significantly different in all fruits and arils physical and chemical quality parameters as shown in Tables 2 and 3. The results indicated that variations between locations and cultivars was expected because each location (elevation) differs in microclimate (light intensity, temperature and humidity), which leads to variation in fruits and arils physical and chemical quality parameters. Fruit weight (FW) was not significantly different between Helow and Malasi cultivars. The Helow and Malasi fruit weight decreased as elevation decreased. Helow scored the highest mean for fruit weight (FW) in Saiq and the lowest in Wakan. Solarte et al. (2014) found that altitude influenced fruit weight of different guava genotypes. Regional Roja and Guavatá Victoria guava genotype in the lower altitude had a higher fruit weight while Regional Blanca and Ráquira Blanca guava genotype reversely affected in higher altitude because of variations between day and night temperatures and higher radiation at lower altitudes that changes the balance between sugar accumulation and degradation resulting in increased fruit weight (Kumari et al., 2019).

Most of the fruits physical quality parameters were influenced by elevation and these increased in both cultivars as elevation increased like total fruit length (FL), fruit length without calyx (FL1), fruit diameter (FD) and rind weight plus weight of capillary membranes (PcMc). 
Table 1. Effects of locations on the color parameters of the cultivars and interaction between location and cultivars.

\begin{tabular}{|c|c|c|c|c|c|c|c|c|c|c|c|}
\hline \multirow{2}{*}{ Location } & \multirow{2}{*}{ Cultivar } & \multicolumn{5}{|c|}{ Fruit color } & \multicolumn{5}{|c|}{ Arils color } \\
\hline & & $\mathbf{L}$ & a & b & Hue & Chroma & $\mathbf{L}$ & a & b & Hue & Chroma \\
\hline \multirow{2}{*}{ Wakan } & Helow & $66.50 \mathrm{~B} \mathrm{c}$ & $-3.29 \mathrm{~B} \mathrm{c}$ & $42.96 \mathrm{~B} \mathrm{a}$ & -1.50 B c & $43.13 \mathrm{~B} \mathrm{a}$ & $76.07 \mathrm{Aa}$ & $-0.14 \mathrm{Bc}$ & $30.17 \mathrm{~A} \mathrm{a}$ & $-0.15 \mathrm{Bc}$ & $30.19 \mathrm{~B} \mathrm{~b}$ \\
\hline & Malasi & $83.54 \mathrm{~A}$ a & $-0.08 \mathrm{~A} \mathrm{~b}$ & $46.67 \mathrm{~A} \mathrm{a}$ & $-0.02 \mathrm{~A} \mathrm{~b}$ & $46.70 \mathrm{~A} \mathrm{a}$ & 59.77 B Ns & 41.78 A Ns & 18.68 B Ns & $0.42 \mathrm{~A} \mathrm{Ns}$ & $45.81 \mathrm{ANs}$ \\
\hline \multirow{2}{*}{ Sograh } & Helow & $82.48 \mathrm{~A} \mathrm{a}$ & $-0.33 \mathrm{~B} \mathrm{~b}$ & $38.15 \mathrm{~A} \mathrm{~b}$ & $-0.27 \mathrm{~B} \mathrm{~b}$ & $38.17 \mathrm{~B} \mathrm{~b}$ & $76.89 \mathrm{~A} \mathrm{a}$ & $5.31 \mathrm{~B} \mathrm{~b}$ & $29.08 \mathrm{Aa}$ & $1.39 \mathrm{~A} \mathrm{a}$ & $29.61 \mathrm{Bb}$ \\
\hline & Malasi & $73.23 \mathrm{~B} \mathrm{~b}$ & $29.54 \mathrm{~A} \mathrm{a}$ & $30.73 \mathrm{~B} \mathrm{~b}$ & $0.81 \mathrm{~A} \mathrm{a}$ & $42.94 \mathrm{~A} \mathrm{~b}$ & 59.36 B Ns & 42.25 A Ns & $18.91 \mathrm{~B} \mathrm{Ns}$ & $0.42 \mathrm{BNs}$ & 46.34 A Ns \\
\hline Saiq & Helow & $75.31 \mathrm{~b}$ & 8.91 a & $33.32 \mathrm{c}$ & $1.31 \mathrm{a}$ & $34.56 \mathrm{c}$ & $70.43 \mathrm{~b}$ & $17.61 \mathrm{a}$ & $27.07 \mathrm{~b}$ & $0.99 \mathrm{~b}$ & 32.36 a \\
\hline \multicolumn{12}{|c|}{ P values } \\
\hline \multicolumn{2}{|c|}{ Cultivar } & $<.0001$ & $<.0001$ & $<.0001$ & $<.0001$ & $<.0001$ & $<.0001$ & $<.0001$ & $<.0001$ & 0.0282 & $<.0001$ \\
\hline \multicolumn{2}{|c|}{ Location } & $<.0001$ & $<.0001$ & $<.0001$ & $<.0001$ & $<.0001$ & $<.0001$ & $<.0001$ & $<.0001$ & $<.0001$ & $<.0001$ \\
\hline \multicolumn{2}{|c|}{ Cultivar"Location } & $<.0001$ & $<.0001$ & $<.0001$ & 0.0265 & 0.1406 & 0.2815 & $<.0001$ & 0.1003 & $<.0001$ & 0.2172 \\
\hline
\end{tabular}

\begin{tabular}{|c|c|c|c|c|c|c|c|c|c|c|c|}
\hline & & \multicolumn{5}{|c|}{ Fruit color } & \multicolumn{5}{|c|}{ Arils color } \\
\hline \multicolumn{2}{|c|}{ Cultivar"Location } & $\mathbf{L}^{* * * *}$ & $a^{* * * *}$ & $\mathbf{b}^{* * * *}$ & Hue $^{*}$ & $\begin{array}{c}\text { Chroma } \\
\text { NS }\end{array}$ & L NS & $a^{* * * *}$ & b NS & $\mathrm{Hue}^{* * * *}$ & $\begin{array}{c}\text { Chroma } \\
\text { NS }\end{array}$ \\
\hline Helow & Saiq & $75.31 \mathrm{c}$ & $8.91 \mathrm{~b}$ & $33.32 \mathrm{~d}$ & $1.31 \mathrm{a}$ & 34.56 & 70.43 & $17.61 \mathrm{c}$ & 27.07 & $0.99 \mathrm{~b}$ & 32.36 \\
\hline Helow & Sograh & $82.48 \mathrm{ab}$ & $-0.33 \mathrm{~cd}$ & $38.15 \mathrm{c}$ & $-0.27 d$ & 38.17 & 76.89 & $5.31 \mathrm{~d}$ & 29.08 & $1.39 \mathrm{a}$ & 29.61 \\
\hline Helow & Wakan & 66.50 e & $-3.29 \mathrm{e}$ & $42.96 \mathrm{~b}$ & $-1.50 \mathrm{e}$ & 43.13 & 76.07 & $-0.14 \mathrm{e}$ & 30.17 & -0.15 e & 30.19 \\
\hline Malasi & Sograh & $73.13 \mathrm{~d}$ & $29.46 \mathrm{a}$ & $30.81 \mathrm{e}$ & $0.80 \mathrm{~b}$ & 42.97 & 59.36 & $42.25 \mathrm{a}$ & 18.91 & $0.42 \mathrm{c}$ & 46.34 \\
\hline Malasi & Wakan & $83.54 \mathrm{a}$ & $-0.08 \mathrm{c}$ & $46.67 \mathrm{a}$ & $-0.02 c$ & 46.70 & 59.77 & $41.78 \mathrm{ab}$ & 18.68 & $0.42 \mathrm{~cd}$ & 45.81 \\
\hline
\end{tabular}

Values marked with different letters in the same column indicate significant differences $(\mathrm{P}<.05)$; ns=not significant. the capital letters in the tables illustrate the difference of cultivars in same location while the small letters illustrate the difference of the same cultivar in different locations. Where $\mathrm{L}$ difference in lightness/darkness value. Negative (L) values indicate darkness and higher positive (L) values indicate a lightness. On the other hand, negative (a) values indicate green and higher positive (a) values indicate a red color. Higher positive (b) values indicate a more yellow skin color and negative (b) indicate a blue color. These values were then used to calculate hue degree, where $0^{\circ}=$ red-purple, $90^{\circ}=$ yellow, $180^{\circ}=$ bluish green, and $270^{\circ}=$ blue, and (Chroma), which indicates the intensity or color saturation (Selcuk and Erkan, 2015). Chroma was calculated using formulas Chroma $=(\mathrm{a} 2+\mathrm{b} 2) 1 / 2$ and Hue $=\arctan \left(b^{*} / a^{*}\right)$.

Orazem et al. (2011) stated that the fruit size was stimulated by genotype in peach fruit (Kumari et al., 2019). In rosehip fruits, physio-chemical features showed significant differences, and these differences were affected by type, genotype and ecological conditions (Eroğul et al., 2018). Skin thickness (Ec) and arils yields (Rs) were significant between Malasi and Helow cultivars and this was expected since they were different. The similar findings of Al-Said et al. (2009) showed that cultivars vary in fruit and aril color, and size at maturity which was also observed in by Hamid et al. (2018). Porterville fruit had low aril yield regardless of their fruit weight. This might be excused by climatic conditions, which possibly favor the growth of membranes more than arils (Opara et al., 2013).

Measured physical and chemical quality parameters of arils of Malasi and Helow cultivars showed variable response to elevation, particularly in aril length (SL) and width (SW) and weight (AW). Differences in aril and seed physical quality parameters were similarly observed by Opara et al. (2013). In the present study, total soluble solids (TSS) was found to increase with increasing altitudes which is in line with Kumari et al. (2019) in their study on physical and biochemical attributes of three Indian apples (Malus demostica Borkh.) cultivars as affected by elevation and genotype. Titratable acidity (TA) was also found to decrease as elevation decreased in Helow cultivar, while Malasi showed no difference in this character between locations. Higher juice volume (JV) was observed in Helow cultivars than Malasi except in Wakan, where it was found lowest in Helow which was expected because of the lowest fruit weight. Malasi was higher in titratable acidity (TA) than Helow and also it was higher in Sograh than in Wakan while in Helow cultivar, it was higher in Wakan and lower in Saiq. Thus, different cultivars responded differently to elevations, which had different microclimates (Opara et al., 2013). Maturity index (MI) was lower in Malasi cultivars than in Helow and also for high titratable acidity (TA) was found in Malasi cultivars (26.6 and 22.9) in Sograh and Wakan, respectively. Seed width was different between locations and cultivars while seed length was no significant between locations but significant between cultivars. Al-Said et al. (2009) observed that cultivars varied in fruit and aril color, and size at maturity and this finding was confirmed our results which showed Woody portion weight (WPW) and woody portion index (WPI) of Helow and Malasi cultivars decreased as the elevation decrease. 
Table 2. Effect of locations and cultivars on Fruit physical quality parameters.

\begin{tabular}{|c|c|c|c|c|c|c|c|c|c|c|c|}
\hline \multirow{2}{*}{ Location } & \multirow[b]{2}{*}{ Cultivar } & \multicolumn{10}{|c|}{$\begin{array}{c}\text { Mean fruit } \\
\text { Dependent Variable }\end{array}$} \\
\hline & & FW (g) & $\begin{array}{c}\text { FD } \\
(\mathbf{m m})\end{array}$ & $\begin{array}{c}\mathrm{CD} \\
(\mathrm{mm})\end{array}$ & $\begin{array}{c}\mathrm{FL} \\
(\mathbf{m m})\end{array}$ & $\begin{array}{c}\text { FL1 } \\
(\mathbf{m m})\end{array}$ & $\begin{array}{c}\mathrm{CL} \\
(\mathrm{mm})\end{array}$ & $\mathrm{Nc}^{\mathrm{NS}}$ & $\begin{array}{l}\text { PcMc } \\
(\mathrm{g})\end{array}$ & $\underset{\text { NS }}{\mathbf{E c}}$ & $\operatorname{Rs}(\%)^{\mathrm{NS}}$ \\
\hline \multirow{2}{*}{ Wakan } & Helow & $261.49 \mathrm{Bc}$ & $80.15 \mathrm{Bb}$ & $23.04 \mathrm{Aa}$ & $68.53 \mathrm{Bb}$ & $82.89 \mathrm{Bb}$ & $14.36 \mathrm{a}$ & 6.10 & $112.79 \mathrm{Bc}$ & $4.31 \mathrm{~B}$ & $55.55 \mathrm{~A}$ \\
\hline & Malasi & $347.60 \mathrm{Ab}$ & $94.79 \mathrm{Ab}$ & $21.22 \mathrm{Ba}$ & $86.39 \mathrm{Ab}$ & $99.87 \mathrm{Ab}$ & 13.48 & 6.10 & $170.72 \mathrm{Ab}$ & $5.06 \mathrm{~A}$ & $49.70 \mathrm{~B}$ \\
\hline \multirow{2}{*}{ Sograh } & Helow & $392.83 \mathrm{~b}$ & $90.30 \mathrm{Ba}$ & $18.86 \mathrm{Ab}$ & $83.53 \mathrm{Ba}$ & $93.29 \mathrm{Ba}$ & $9.76 \mathrm{~b}$ & 6.47 & $172.63 \mathrm{Bb}$ & $4.71 \mathrm{~A}$ & $55.30 \mathrm{~A}$ \\
\hline & Malasi & 407.50 a & $108.45 \mathrm{Aa}$ & $17.89 \mathrm{Ab}$ & $102.86 \mathrm{Aa}$ & $114.92 \mathrm{Aa}$ & 12.06 & 6.04 & $212.34 \mathrm{Aa}$ & $5.09 \mathrm{~A}$ & $48.78 \mathrm{~B}$ \\
\hline \multirow{2}{*}{ Saiq } & Helow & 464.72 a & $93.10 \mathrm{a}$ & 23.15 a & $81.89 \mathrm{a}$ & 97.11 a & $15.22 \mathrm{a}$ & 6.52 & 207.24 a & 4.40 & 55.38 \\
\hline & Malasi & - & - & - & - & - & - & - & - & - & - \\
\hline \multicolumn{12}{|c|}{$P$ values } \\
\hline \multicolumn{2}{|c|}{ Year } & 0.6424 & 0.1462 & $<.0001$ & 0.005 & 0.1374 & 0.0042 & 0.0257 & 0.0322 & 0.0014 & $<.0001$ \\
\hline \multicolumn{2}{|c|}{ Location } & $<.0001$ & 0.0001 & 0.2051 & $<.0001$ & $<.0001$ & 0.0002 & 0.2244 & $<.0001$ & 0.7176 & 0.9996 \\
\hline \multicolumn{2}{|c|}{ Cultivar } & 0.0082 & $<.0001$ & $<.0001$ & $<.0001$ & $<.0001$ & 0.4399 & 0.1422 & $<.0001$ & 0.0328 & 0.0024 \\
\hline \multicolumn{2}{|c|}{ Location*Cultivar } & 0.0676 & 0.4478 & 0.4206 & 0.9303 & 0.4116 & 0.1416 & 0.0418 & 0.3175 & 0.3125 & 0.9010 \\
\hline
\end{tabular}

Values marked with different letters in the same column indicate significant differences $(\mathrm{P}<.05)$; ns=not significant. The capital letters in the tables illustrate the difference of cultivars in same location while the small letters illustrate the difference of the same cultivar in different locations. fruit weight (FW), total fruit length (FL), fruit length without calyx (FL1), calyx length (CL), fruit diameter (FD), calyx diameter (CD), number of carpels (Nc), rind weight plus weight of capillary membranes (PcMc), skin thickness (Ec) and arils yield (Rs).

Table 3. Effect of locations and cultivars on arils physical and chemical quality parameters.

\begin{tabular}{|c|c|c|c|c|c|c|c|c|c|c|c|c|}
\hline \multirow{3}{*}{ Location } & \multirow{3}{*}{ Cultivar } & \multicolumn{11}{|c|}{ Mean seed } \\
\hline & & \multicolumn{3}{|c|}{ Aril Physical Properties } & \multicolumn{4}{|c|}{ Aril Chemical Properties } & \multicolumn{4}{|c|}{ Seed Physical Properties } \\
\hline & & $\begin{array}{c}\text { SW } \\
(\mathbf{m m})\end{array}$ & $\begin{array}{c}\text { SL } \\
(\mathbf{m m})\end{array}$ & $\begin{array}{l}\text { AW } \\
(\mathbf{m g})\end{array}$ & $\begin{array}{l}\text { JV } \\
(\mathbf{m l})\end{array}$ & $\begin{array}{c}\text { TSS } \\
\left({ }^{\circ} \text { Brix }\right)\end{array}$ & TA & MI & $\begin{array}{c}\mathrm{W} \\
(\mathrm{mm})\end{array}$ & $\begin{array}{c}\mathrm{L} \\
(\mathrm{mm})\end{array}$ & $\begin{array}{c}\text { WPW } \\
\text { (mg) }\end{array}$ & WPI \% \\
\hline \multirow{2}{*}{ Wakan } & Helow & $5.80 \mathrm{~b}$ & $9.34 \mathrm{Ab}$ & $0.19 \mathrm{Bb}$ & $68.87 \mathrm{Bc}$ & $12.20 \mathrm{Bc}$ & $6.10 \mathrm{Ba}$ & $2.08 \mathrm{Ac}$ & $2.64 \mathrm{Bb}$ & $6.79 \mathrm{Aa}$ & $0.03 \mathrm{c}$ & $0.53 \mathrm{c}$ \\
\hline & Malasi & $6.04 \mathrm{a}$ & $8.50 \mathrm{Bb}$ & $0.26 \mathrm{Aa}$ & $105.75 \mathrm{Aa}$ & $16.23 \mathrm{Aa}$ & $22.94 \mathrm{Ab}$ & $0.82 \mathrm{Bb}$ & $3.63 \mathrm{Aa}$ & $6.28 \mathrm{Ba}$ & $0.03 \mathrm{~b}$ & $0.50 \mathrm{~b}$ \\
\hline \multirow{2}{*}{ Sograh } & Helow & $6.50 \mathrm{a}$ & 10.52 Aa & $0.29 \mathrm{Aa}$ & $120.03 \mathrm{Ab}$ & $14.12 \mathrm{Bb}$ & $5.88 \mathrm{Ba}$ & $2.52 \mathrm{Ab}$ & $3.20 \mathrm{Aa}$ & $6.84 \mathrm{Aa}$ & $0.04 \mathrm{~b}$ & $0.60 \mathrm{~b}$ \\
\hline & Malasi & $5.82 \mathrm{~b}$ & $9.39 \mathrm{Ba}$ & $0.25 \mathrm{Bb}$ & $109.64 \mathrm{Ba}$ & $16.41 \mathrm{Aa}$ & $26.65 \mathrm{Aa}$ & $0.66 \mathrm{Ba}$ & $2.66 \mathrm{Bb}$ & $6.32 \mathrm{Ba}$ & 0.04 a & $0.62 \mathrm{a}$ \\
\hline Saiq & Helow & $5.92 \mathrm{~b}$ & $9.56 \mathrm{~b}$ & $0.30 \mathrm{a}$ & $134.10 \mathrm{a}$ & $15.65 \mathrm{a}$ & $4.75 \mathrm{~b}$ & $3.96 \mathrm{a}$ & $2.70 \mathrm{~b}$ & $6.64 \mathrm{a}$ & $0.041 \mathrm{a}$ & $0.74 \mathrm{a}$ \\
\hline \multicolumn{13}{|c|}{$P$ values } \\
\hline \multicolumn{2}{|c|}{ Location } & $<.0001$ & $<.0001$ & $<.0001$ & $<.0001$ & $<.0001$ & 0.0002 & $<.0001$ & 0.0021 & 0.0215 & $<.0001$ & $<.0001$ \\
\hline \multicolumn{2}{|c|}{ Cultivar } & 0.1937 & $<.0001$ & 0.0345 & $<.0001$ & $<.0001$ & $<.0001$ & $<.0001$ & 0.0023 & $<.0001$ & 0.0331 & 0.2056 \\
\hline \multicolumn{2}{|c|}{ Location*Cultivar } & $<.0001$ & 0.9059 & $<.0001$ & $<.0001$ & $<.0001$ & $<.0001$ & 0.004 & $<.0001$ & 0.4567 & 0.9485 & 0.8425 \\
\hline
\end{tabular}

\begin{tabular}{|c|c|c|c|c|c|c|c|c|c|c|c|c|}
\hline \multirow{2}{*}{\multicolumn{2}{|c|}{ Cultivar"Location }} & \multicolumn{3}{|c|}{ Aril Physical Properties } & \multicolumn{4}{|c|}{ Aril Chemical Properties } & \multicolumn{4}{|c|}{ Seed Physical Properties } \\
\hline & & $\begin{array}{c}\text { SW } \\
(\mathbf{m m}) \\
\text { NS }\end{array}$ & $\begin{array}{c}\text { SL } \\
(\mathbf{m m}) \\
\mathrm{NS}\end{array}$ & AW *** & $\mathrm{JV}(\mathrm{ml})^{* * *}$ & TSS $^{* * *}$ & $\mathbf{T A}^{* * *}$ & M1** & $\begin{array}{c}\mathbf{W} \\
(\mathbf{m m}) \\
\mathbf{N S}\end{array}$ & $\begin{array}{c}\mathrm{L} \\
(\mathrm{mm}) \\
\mathrm{NS}\end{array}$ & $\begin{array}{c}\text { WPW } \\
\text { NS }\end{array}$ & $\begin{array}{l}\text { WPI } \\
\text { NS }\end{array}$ \\
\hline Helow & Saiq & 5.92 & 9.56 & $0.30 \mathrm{a}$ & $134.10 \mathrm{a}$ & $15.65 \mathrm{c}$ & $4.745 \mathrm{cde}$ & $3.96 \mathrm{a}$ & $2.70 \mathrm{c}$ & 6.64 & 0.04 & 0.74 \\
\hline Helow & Sograh & 6.50 & 10.52 & $0.29 \mathrm{ab}$ & $120.03 \mathrm{~b}$ & $14.12 \mathrm{~d}$ & $5.88 \mathrm{~cd}$ & $2.52 \mathrm{~b}$ & $3.20 \mathrm{~b}$ & 6.84 & 0.04 & 0.60 \\
\hline Helow & Wakan & 5.80 & 9.34 & $0.19 \mathrm{e}$ & 68.87 e & $12.20 \mathrm{e}$ & $6.10 \mathrm{c}$ & $2.06 \mathrm{c}$ & 2.64 cde & 6.79 & 0.03 & 0.53 \\
\hline Malasi & Sograh & 6.03 & 9.65 & $0.25 \mathrm{~cd}$ & $112.30 \mathrm{bc}$ & $16.76 \mathrm{a}$ & $26.92 \mathrm{a}$ & 0.64 de & $2.69 \mathrm{~cd}$ & 6.43 & 0.03 & 0.58 \\
\hline Malasi & Wakan & 6.04 & 8.50 & $0.26 \mathrm{c}$ & $105.75 \mathrm{~cd}$ & $16.23 \mathrm{~b}$ & $22.94 \mathrm{~b}$ & $0.82 \mathrm{~d}$ & $3.63 \mathrm{a}$ & 6.28 & 0.03 & 0.50 \\
\hline
\end{tabular}

Values marked with different letters in the same column indicate significant differences $(\mathrm{P}<.05)$; ns=not significant. The capital letters in the tables illustrate the difference of cultivars in same location while the small letters illustrate the difference of the same cultivar in different locations. arils width (SW), arils length (SL), Aril weight (AW), juice volume (JV), total soluble solid (TSS), titratable acidity (TA), Maturity index (MI), seed width (W), seed length (L), woody portion weight (WPW) and woody portion index (WPI). 


\section{Conclusion}

The results led to conclusion that Helow cultivar performed better in Saiq which was at the highest elevation as compared to those grown at mid-elevation in Sograh and at lower altitude in Wakan in terms of fruit color, fruit and aril physical and chemical quality parameters. As the elevation decreased the fruit and aril quality of Helow cultivar also decreased. However, quality measurements of Malasi cultivar showed no differences between Sograh and Wakan in fruit and arils color, physical and chemical quality parameters. Traditional pomegranate farmers by their inherited experience, rarely grow Malasi cultivar at higher elevations and they know for certain that the quality could not be the same as when it was grown at lower elevation. However, Helow, a highly popular cultivar, showed the opposite and quality was best at higher altitudes. The effect of micro-climate (light intensity, temperature and humidity) on the quality of pomegranate cultivars need to be studied with a wide range of cultivars and also on different deciduous fruit crops to determine their impact on fruit physical quality (such as color development) and edible chemical qualities, such as TSS \& TA. This could help growers to select suitable cultivars for each elevation and predict the future of pomegranate cultivation in marginal mountainous regions of the world, as temperature might change due to global warming. The results of this study contributed to adaptation mechanisms of mitigating the impact of climate change, particularly rising temperatures, which has significant importance in the conservation of local genotypes of deciduous fruit crops grown in Al-Hajar Mountain of Oman.

\section{References}

AOAC. (2000). Official Methods of Analysis. Association of Analytical Chemists, Rockville, MD, US.

Al-Said FA, Al-Yahyai RA, Opara UL. (2013). Traditional cultivation of pomegranate in Oman. Acta Horticulture 1007: 549-555.

Al-Said F, Opara L, Al-Yahyai R. (2009). Physico-chemical and textural quality attributes of pomegranate cultivars (Punica granatum L.) grown in the Sultanate of Oman. Journal of Food Engineering 90:129-134.

Al-Yahyai R, Al-Said F, Opara L. (2009). Fruit growth characteristics of four pomegranate cultivars from northern Oman. Fruits 64(6): 335-341.

Bilalis D, Krokida M, Roussis I, Papastylianou P, Travlos I, Cheimona N, Dede A. (2018). Effects of organic and inorganic fertilization on yield and quality of processing tomato (Lycopersicon esculentum Mill.). Folia Horticulturae 30(2): 321-332.

Boussaa F, Zaouay F, Burlo-Carbonell F, Noguera-Artiaga L, Carbonell-Barrachina A, Melgarejo P, Mars, M. (2020). Growing Location Affects Physical Properties,
Bioactive Compounds, and Antioxidant Activity of Pomegranate Fruit (Punica granatum L. var. Gabsi). International Journal of Fruit Science 20(2): 508-523.

El-Salhy, AM, Ibrahim, RA, Abou-Zaid, EA, \& Ali, MA. (2019). Comparative Study of some Pomegranate Cultivars (Punica granatum L.) Under Assiut Climatic Conditions. Assiut Journal of Agricultural Sciences 50(3): 134-149.

Eroğul D, Oğuz HI. (2018). Determining the Physico-Chemical Characterstics of the Rosehip Genotypes Grown Naturally in Adiyaman Province. Erwerbs-Obstbau 60(3): 195-201.

Hmid I, Hanine H, Elothmani D, Oukabli A. (2018). The physico-chemical characteristics of Morrocan pomegranate and evaluation of the antioxidant activity for their juices. Journal of the Saudi Society of Agricultural Sciences 17(3): 302-309.

Karagiannis E, Tanou G, Samiotaki M, Michailidis M, Diamantidis G, Minas IS, Molassiotis A. (2016). Comparative physiological and proteomic analysis reveal distinct regulation of peach skin quality traits by altitude. Frontiers in Plant Science 7: 1-14.

Kumar P, Sethi S, Sharma RR, Singh S, Saha S, Sharma VK, Varghese E. (2019). Influence of altitudinal variation on the physical and biochemical characteristics of apple (Malus demostica). Indian Journal of Agricultural Sciences 89(1): 145-152.

Martínez-Nicolás, JJ, Galindo A, Griñán I, Rodríguez P, Cruz ZN, Martínez-Font R, Melgarejo P. (2019). Irrigation water saving during pomegranate flowering and fruit set period do not affect Wonderful and Mollar de Elche cultivars yield and fruit composition. Agricultural Water Management 226: 1-1.

Mditshwa A, Fawole OA, Al-Said F, Al-Yahyai R, Opara UL. (2013). Phytochemical content, antioxidant capacity and physicochemical properties of pomegranate grown in different microclimates in South Africa. South African Journal of Plant and Soil 30(2): 81-90.

Melgarejo P, Melgarejo-Sánchez P, Martínez JJ, Hernández F, Legua P, Martínez R. (2013). The pomegranate tree in the world: new cultivars and uses. III International Symposium on Pomegranate and Minor Mediterranean Fruits 1089: 327-332.

Mphahlele RR, Caleb OJ, Fawole OA, Opara UL. (2016). Effects of different maturity stages and growing locations on changes in chemical, biochemical and aroma volatile composition of 'Wonderful'pomegranate juice. Journal of the Science of Food and Agriculture 96(3): 1002-1009.

Naryal A, Acharya S, Bhardwaj AK, Kant A, Chaurasia OP, Stobdan, T. (2019). Altitudinal effect on sugar contents and sugar profiles in dried apricot (Prunus armeniaca L.) fruit. Journal of Food Composition and Analysis 76: 27-32. 
Nour V, Ionica ME, Trandafir I. (2015). Bioactive compounds, antioxidant activity and color of hydroponic tomato fruits at different stages of ripening. Notulae Botanicae Horti Agrobotanici Cluj- 43(2): 404-412.

Orazem P, Stampar F, Hudina M. (2011). Fruit quality of redhaven and royal glory peach cultivars on seven different rootstocks. Journal of Agricultural and Food Chemistry 59: 9394-401.

Peng Y, Wang G, Cao F, Fu, FF. (2020). Collection and evaluation of thirty-seven pomegranate germplasm resources. Applied Biological Chemistry 63(1): 1-15.

SanchoLE,YahiaEM,González-Aguilar,GA.(2011).Identification and quantification of phenols, carotenoids, and vitamin $\mathrm{C}$ from papaya (Carica papaya L., cv. Maradol) fruit determined by HPLC-DAD-MS/MSESI. Food Research International 44(5): 1284-1291.
Selcuk N, Erkan M. (2015). Changes in phenolic compounds and antioxidant activity of sour-sweet pomegranates cv. 'Hicaznar'during long-term storage under modified atmosphere packaging. Postharvest Biology and Technology 109: 30-39.

Solarte ME, Melgarejo LM, Martínez O, Hernández MS, Fernández-Trujillo, JP. (2014). Fruit quality during ripening of Colombian guava (Psidium guajava L.) grown at different altitudes. Journal of Food, Agriculture \& Environment 12(2): 669-675. 